\title{
English Communication Competence: Expectations and Challenges (A Case in Indonesia)
}

\author{
Dwi Poedjiastutie ${ }^{1 *}$, Zetty Aqmi Amrin², Yongki Setiawan ${ }^{2}$ \\ ${ }^{1}$ University of Muhammadiyah Malang, Indonesia \\ ${ }^{2}$ Postgraduate Program of University of Muhammadiyah Malang, Indonesia
}

Corresponding Author: Dwi Poedjiastutie, E-mail: dpoedjiastutie@yahoo.com

\section{ARTICLE INFO \\ Article history \\ Received: May 29, 2018 \\ Accepted: August 26, 2018 \\ Published: November 01, 2018 \\ Volume: 7 Issue: 6 \\ Advance access: September 2018}

Conflicts of interest: None

Funding: None

\begin{abstract}
English communication in Indonesian schools poses a lot of challenges. These are especially related to the factors involved in education as secondary school curriculum. Indonesia high school curriculums are usually constructed using top-down approach. This approach is suspected to contribute students' communication development at later stage in university level. Communication courses at tertiary level are expected to equip students with more advanced communication level than at secondary school so the gradual development of students' communication level can be attained. Several researches have been conducted to disclose those issues. However, a little attention is given to reveal the expectations and challenges from both students and teachers respectively. Due to that, this study is intended to examine factors inhibit the development of communication competence of the university students. An interpretive research paradigm was employed in this study. Speaking teachers at English Department (ED) were selected using convenient sampling. Expectation and challenges of developing communication level at DS University (DSU) are revealed from both students and teachers. Both cohorts expect the English Department Chairman to take serious steps to face upcoming globalization in which improving communication competence of ED graduates are urgent.
\end{abstract}

Key words: Needs Analysis, Interpretive Study, Communication Competence, Communication Challenges, High School Curriculums

\section{INTRODUCTION}

The fact that English in Indonesia is falling behind other Asian countries have been disclosed by a survey conducted by English Proficiency Index (EPI) in 2017. There were eighty countries participated in this survey and found Indonesia posited in $39^{\text {th }}$ falling behind Singapore $\left(5^{\text {th }}\right)$, Malaysia $\left(13^{\text {nd }}\right)$, The Philippines $\left(15^{\text {rd }}\right)$ and Vietnam $\left(34^{\text {th }}\right)$. The survey uses English components such as grammar, reading comprehension, and communication as the proficiency indicators. It is unfortunate that English language development in Indonesia is still far left behind other Asian countries.

This issue should be carefully taken into account by Indonesia Government especially when nowadays many Asian countries also attempt to find out a solution of English teaching challenges in order to meet future demand and move toward globalization. As a matter of fact, the integration of ASEAN Economic Competition (AEC) in 2020 which is just in two years ahead requires human resources who are ready to compete in all sectors such as politics, diplomacy, international trade and industry, commerce, science and technology, education, media and information technology (Crystal, 2003; Jenkins, 2003; Huda, 2000).

In many areas, English has been proven to have a strong connection with the employability level. Employability level is defined as wider opportunity for the applicants to be accepted in jobs. In Asia context, this commonly depends on applicants' level of English specifically the ability to communicate in English. Although Coleman (2010) in his earlier studies have failed to provide evidence linking English competence to workplaces, other recent studies proved differently and scored positive relationship between English competence and employability level. Therefore. Due to the international value of English as a lingua franca, it has led to a commitment by the government of Indonesia to oblige the teaching of English from lower to upper high schools and this still continue to occur at tertiary level. Many students at tertiary level is now aware the relevance of having communication competence to their future careers. However, English curriculums in university frequently are not connected to students' future goals and needs (Poedjiastutie and Oliver, 2017). Therefore, it is arguably that the disconnection between the English curriculum and students' future goals may lead to graduates' disappointment since the values of their educational investment are unavailing. The low communication competence will definitely disadvantage students since they are now approaching the era where job competitions are not only among their peers and counterparts inside but also outside the country.

In bigger picture, we cannot blame university curriculum as single factor to contribute the failure of communication 
development in Indonesia. If we take a careful consideration, students' communication experiences are contradicted with Kayi's (2006) claim. He said that not all language teachers in high schools provide maximum opportunity for students to use the target language for communication.

High school leavers commonly choose to continue their study at university and DS University (DSU) is one of their higher education institution destination. This university is the largest private university in East Java Province Indonesia with a total of 18,000 students across Indonesia and overseas studying in all departments and faculties at DSU. The English Department (ED) is the most frequently selected higher education destination for senior high school leavers. Since its establishment, the ED DSU accepts approximately 250 students each year (ED Tracer Study Team, 2016).

\section{The Research Setting}

Providing opportunities for students to use the language at its widest point has been ED DSU's commitment.

ED DSU has designed compulsory courses for communication -Basic Speaking level, Pre- Intermediate Speaking level, Intermediate and Advanced Speaking, to be included in the curriculum. The time allocated for studying each speaking course is 100 minutes each meeting with 16 meetings in total in a semester. These speaking courses are expected to give a wide range of opportunity for students to practice English. The aims of speaking subjects are to train students skills to speak in many kinds of activity. In addition to compulsory speaking courses, the ED DSU also provides several English exposure programs such as English Weekly Discussion, English Day, Student Day, English for Specific Purposes (ESP) and English exposure facilities such as American Corner, Australia Corners, and International Student Office. From the preliminary study on students' initial communication level, it was found that majority students face challenges in English communication. Therefore, the objective of this study is to discover factors causing the underdeveloped communication competence of ED students at DSU. Therefore, the research question is formulated below:

What factors contribute to the underdevelopment of English communicative competence of the ED DSU students?

\section{THEORETICAL FRAMEWORK}

Teaching speaking in Indonesian schools poses a lot of challenges. Several researches have been done to disclose those issues. The discussions in this section are especially related to the groups of people who take significant roles in education system: students, teachers, English Department and management.

\section{Challenges of English Communication Development From Students}

In regards to students' factors, plenty of studies have been conducted. Senel (2012) and Febrianty (2011) found that students have a little opportunity to practice in English class. They keep using their own language even in English class- rooms. Students are also feeling fear and worry of making mistakes or simply shy of getting people attention on their speech and it was exacerbated by other factors such as insufficient vocabulary, low grammatical skill (Hosni, 2014; Hamad, 2013; Munjayanah, 2004). In addition, He and Chen (2010) found that lack of confidence has caused the communication problem among them. They often feel anxious when they talk with classmates or in public. Rabab'ah (2015), states that inadequate knowledge of strategic competence and communication competence was the reason for not being able to keep interaction going. Hamad (2013), also examined the causes of English speaking problems include excessive use of mother tongue, fear of making mistakes, inefficient teaching delivery and lack of practices in speaking classes both at secondary schools and university.

\section{Challenges Of Communication Development From Teachers}

In addition to students, teachers possess critical roles in developing students' communication. Despite their significant role, many Indonesian teachers have been found to lack of teaching competence (Azra, 2002).

One of the indicators of having good teaching competence is the capability of using the target language. As a matter of fact, many teachers excessively use Bahasa Indonesia (L1) in teaching English. A study conducted by Agustin, Warsono and Mujianto reported that the use of Bahasa Indonesia (L1) in teaching English (L2) cannot be avoided. According to these teachers Bahasa Indonesia helps clarifying the in-struction. However, if teachers used predominantly L1 way too much, it may cause dependence on linguistic transfer.

Other issue was many teachers were not quite familiar with learner's centred approach. Learner centred approach is believed to create a more conducive learning and promote the highest levels of motivation, (McCombs \& Whisler, 1997).

Azra (2002) and Bjork (2005) found in their study that lack of teaching competence of Indonesian teachers has led them to use teacher-centered and rote learning which provides students little chance to interact (Zuhdi, 2015). They just listen to the teacher most of the time and teachers give little opportunity for students to communicate their ideas. It is obvious that in teacher-centered approach, students' communication development was not prevalent.

\section{Challenges Of Communication Development From The Government}

Holliday (1994) observes that many English teachers in the countries where English is a foreign language (i.e., in an EFL context) the communicative methodology is problematic since English is taught as part of the wider (often national) curriculum which is generally top-down process. The schools as the executor of curriculum was unable to develop their own creative programs fits for the students' characteristics and communication needs since all the curriculum guideline must be strictly followed and the objectives should be all achieved if the schools want to be accredited. This 
"one size curriculum fits all" is in stark contrast with the diverse characteristics of students in Indonesia. The diversities make any centralized curriculum fail to address specific needs of students who come from different geographical areas. Therefore, this top-down process was suspected to contribute a failure in developing English communication competence in high schools. It does affect students' communication development at tertiary level where students usually continue their study.

This current study is to discover factors contribute to the development of communication competence at DSU.

\section{METHODOLOGY}

\section{Research Design}

This is qualitative research in nature. An interpretive research paradigm was employed in the proposed research. In an interpretive research paradigm, theories are constructed from the data rather than theories preceding the data (Erlandson, Harris, Skipper, \& Allen, 1993). The data in this research is the participants' goals, reasons, motives, feelings, perspectives, and assumptions (Fraenkel, Wallen, \& Hyun (2012).

\section{Research Participants}

The participants include ED DSU students who enrolled in all academic year and ED teachers especially those who are teaching communication class. There are 24 students from different academic years attended Focus Group Discussions (FGD). Each FGD consisted of 8 students.

In addition to FGD, 10 teachers were willing to participate in the interview. Individual teacher was interviewed in their own convenient time and venue. Each interview took about 30 minutes. Convenient Sampling was employed in this study.

\section{Research Procedures and Data Collection Tools}

In this study, two stages of data collection and data analysis were conducted to get an overall understanding of factors contributing to the undeveloped communication competences of the learners.

The first step is learners' perceptions were ascertained using focus group Discussion. Students from each academic year were invited to attend. Each focus group was attended up to 8 students, as this has been found to be the optimum number of participants for focus group research (Fraenkel, et.al, 2012, p. 423). Different focus groups were conducted until it emerges from the ongoing thematic analysis of responses that no more new perspectives are revealed, that is until saturation point is reached.

Second, interviews with ED speaking teachers were conducted. The interviews gave opportunity for the participants to express their reasons, feelings, an/or opinions regarding to teaching delivery and the challenges they may face in handling the communication classes. To facilitate this, Semi-structured interviews were conducted with the teachers and this was done individually. Each interview is expected to last 30 minutes. Semi-structured interview was employed so that factors or the reasons of undeveloped communication competence can be explored in depth if needed. The interviews were recorded, transcribed (Miles \& Huberman, 1994) and coded according to the themes emerge.

A process of constant-comparative analysis was employed to analyse the data obtained through the focus group interviews with students and individual interview with teachers, the responses from students and teachers at ED DSU were compared to find out consistencies and new typological dimensions (Lincoln \& Guba, 1985, p. 335) or it is known as new categories. The data collection procedures and analysis are described in the following figure:

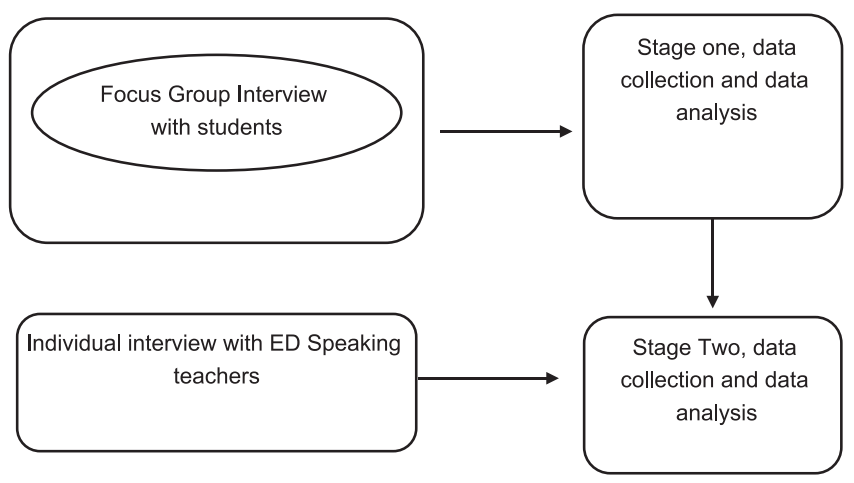

\section{Trustworthiness}

This research is guided by the constructivism quality standard to ensure trustworthiness (Guba and Lincoln (1989) quoted in Bryman, 2012). The following describes these quality standards.

\section{Credibility}

Credibility refers to whether the participants' data is accurately identified and described. all data obtained from interviews were transcribed and returned to the participants in order for them to check whether the transcriptions made by the researcher accurately represent what they have said.

\section{Transferability}

As it has been explained in the data collection section above, this study compares the results from students' FGD and teachers' interviews. As Fraenkel, et.al, (2012) argue that "When a conclusion is supported by data collected from a number of different instruments, its transferability is thereby enhanced. This is often referred to as triangulation" (p. 458).

\section{Confirmability}

Confirmability means that "Data (constructs, assertions, and facts) can be tracked to their sources, and that the logic used to assemble the interpretations into structurally and coherent and corroborating wholes is both explicit and implicit in the narrative of a case study" (Guba \& Lincoln, 1989, p.243). 
Since recording devices- video and tape were used in interviews, this device provided data tracking whenever the clarifications are needed.

\section{RESULTS AND DISCUSSIONS}

The presentation of the findings integrates the results of both interview and FGD. The researchers create categories to organize the data. The data fall into three categories:

\section{Teacher Factors}

\section{Different expectations of communication goals}

Many teachers had different perspectives when expressing the goal of teaching speaking. According to them, students should be able to use English as a communication tool and being able to speak intelligibly and adequately for global communication.

Some expressed more specific expectations that speaking courses should be designed for students' future academic and careers pursuit. In the academic pursuit, students may want to go for higher degree or scholarship benefits; whereas in career pursuit, they may need to communicate for their daily teaching business. In globalization era, ED DSU graduates may possibly compete for teaching jobs overseas. Even if they apply for teaching jobs inside the country, English graduates will be assessed in their communication capability. This capability will help schools to establish network and cooperation with other schools both inside and outside the country.

Furthermore, other teachers expected the speaking courses should equip students to be proficient English speakers understood by people from different cultures regardless their ethnicity groups and nationalities. That is to say communication competence should not only the focus but maintaining communication flow is also useful.

In brief, teachers have variety expectations regarding to the goals of speaking courses from the general to specific academic to teaching career pursuit, as well as cultural competence communication.

\section{Teachers' indifferent attitudes toward the speaking syllabuses}

Despite their big responsibility in improving students' communication competence, almost no teacher follow the speaking syllabus as the guidelines of their classroom teachings. Many of them claim that speaking syllabuses were design without prior Needs Analysis (NA). Therefore, they urged to modify the syllabus to meet students' expectations and goals of learning.

However, when they were asked to clarify their opinions further, some admitted that they never read the documents. Moreover, they also admitted that they neither followed the syllabuses nor did systematic NA of their own. One of them said that she was given teaching schedules a little late so she just picked any topics which according to her fit with Basic Speaking level.
Some teachers interviewed expressed dubious opinions. In one hand, they claimed that modifying the syllabus is what ED DSU must do in order to be able to improve students' communication level. However, they also did not know for sure which speaking topics and materials need to maintain and which ones are supposed to replace to fit students' expectations. The hesitant attitudes and unsystematic ways of assessing speaking materials may put students at a risk of not being able to develop their communication potentials.

\section{Teachers'teaching beliefs}

The teacher's beliefs about how speaking should be taught may affect their delivery. No matter how current the syllabuses is, they will end up teaching communication the way it fits their beliefs. For example, one teacher believed that graduates were prepared to be a teacher of high school who strengthens knowledge for senior high school students to succeed in national examinations. Due to this belief, she objected to have fun for her English class such as casual communication or speaking games and song analysis.

Actually, we need to revise syllabus. As I see, some lecturers teach the students like teaching senior high school students by having kind of singing a song. I quite disagree with that. We have to know that they are adult learners, they have purpose to be a teacher of junior or senior high school which they have to face examination, so no need to teach them to sing a song all the time.

Some teachers, on the other hand, believed that showing the direction of students' learning will eventually lead students to developing their communication skills. This teacher expected students to practice communication not only during the class meeting under the supervision of teachers but also outside the class even when teachers did not present.

\section{Student Factors}

\section{The students' expectations on communication goals}

To be able to communicate was students' first priority to learn English at ED DSU and many of them said that having higher level of communication was critical. Many students agree that communication will help them to secure in job competition. However, the expectations were partially different from the speaking teachers. As mentioned earlier teachers wanted the communication syllabuses were directed to meet students' communication competence for general English (GE), Academic English (AE), Occupational English (OE) especially teaching purposes and understanding cultures. Meanwhile graduates of ED wanted to be able to communicate for jobs other than teaching such as international motivators, translation center, flight attendance, teachers of overseas higher education. Below is one example taken from students' assertion:

I think communication is also important to market or to promote the existence of this business. I think it is useless if we run business but no one knows the business so communication is important to spread the information to wider community. 
Students considered three types of communication areas: presentation, discussion, and negotiation skills are important for their future life whether they were going into a particular job or pursuing higher education. They expected that teachers should equip and integrate these skills in communication courses.

\section{The students' preference of speaking teachers}

Students have different expectations regarding to speaking teachers. Some of them preferred to have English native speakers in their communication class. When they were asked further about their understanding of native speakers, they have different answers. Some said that native speaker is someone from English speaking countries such as United States, Australia, British, and New Zealand. However, others said that as long as they did not speak their local language or Bahasa Indonesia even though English was not their first language, they are supposed to teach communication. This will enforce students to use any strategy to convey the messages without using Indonesian.

When I cannot deliver my opinion in English, I will try my best in whatsoever I can to make him understand what I am saying. But if the lecturer is Indonesian, I will have a tendency to use my Bahasa Indonesia.

Some students expressed that it did not really matter where the teachers were from. Teachers should be really having high communication and critical thinking level so that they can give valuable feedback. According to these students the communication competence matters much compared to their country of origin.

Others expressed concerns about foreign teachers. According to these students, they did not even know what to teach in speaking subject. These teachers chose topics and teaching materials related to their own background of knowledge in which these materials did not suit students' needs. Students expressed suggestion for ED chairman should carefully take into account several aspects before giving teaching appointment to foreign teachers. The example below is excerpt from students:

My speaking teachers were from overseas. She taught us mostly something related to financial, management and it made me think that actually we did not need these materials. At first, we never know what her academic background but when she frequently taught about ATM and piggy bank and some kinds of materials, we thought that she had management background. She did not know what she should teach us as the ED students. Sometimes, they forced us to agree and say that you are wrong and I'm right. So, it is impacted to students' skill of communication. And native speakers should not use whatever they want to use in their teaching. They should know at least our cultures too.

However, students expressed concerns not only about foreign teachers but also about local teachers. Local teachers' capacity and delivery skills need to be securitized. Students at FGD states that the communication classes were far from being interesting. Many teachers focus on the grammar and thus, frightened students to communicate more. The topics given by the lecturer was not interesting either. Students said that the speaking materials were similar to what they had learnt when they were at secondary school. They expect more challenging materials to improve and add up the vocabulary and expect to learn more so that their English expressions are nearly native alike.

\section{Speaking teachers' commitment}

Students also expressed that the cause of their undeveloped speaking level and skills was due to the teacher's lack of determination. Teachers' strong commitment and determination enforce students to speak the target language not only in class but also outside the class. In addition, ED chairman's determination plays crucial steps to reduce the teachers' undesirable attitudes. At Group discussion, students expressed concerns that some teachers were coming very late for the class and some skipped class without prior notices. The ED chairmen were supposed to remind these teachers and not just to let these things happened over and over.

The first important thing we need is the effectiveness of teaching and process. Effective here is "no wasting time", but we can get more good results. But, up to now, I still don't get anything yet. What I mean here is, the lecturer should give us various materials, so that we can get more knowledge and improve our speaking skill. Sometimes, the lecturer only focuses on one material for few meetings, that makes us really bored. The last important thing is the commitment of lecturer's attendance. My speaking lecturer has so many absences for this semester. She/he missed the class very often.

\section{Students'learning cultures}

Many also realize that the inadequacy of communication skills were not only due to the teacher's factors as quite a few of them did not seem ready to face challenges and prepare to face different experiences of university learning. For example, students were accustomed to rote learning. Therefore, it was not easy to change cultures from rote learning to more active participation especially when dealing with communication classes. This learning cultures have been shaped and cultivated since students' secondary level. In this situation, speaking teachers should be able to create an atmosphere to grow students' confidence.

Many expressed regrets that their speaking skills did not improve significantly even though they almost finished all speaking subjects. Some students said that unless they are willing to participate in English exposure programs established by ED (English Day and, English Weekly Discussion), they may still have the opportunity to improve their communication level. Many students, however, kept using the local language on the English Day., except for very highly motivated students. As students enrolled in university for different reasons and their reasons determined their level of motivation. And so far, the ED DSU has not yet designed systematic ways to increase the number of students' participation on the English Exposure programs. 


\section{English Department Management Factors}

\section{Speaking teachers' recruitment system}

The success classroom businesses often rely on teachers' capacity. Therefore, assigning Speaking courses to the right teachers need to be deliberately taken into account. This allegation was explicitly expressed due to the innapropriate appointment of speaking teachers. ED DSU currently appoints speaking teachers from overseas without paying careful attention to their qualifications. The only consideration is they did not speak Bahasa Indonesia to students. Those foreign teachers purpose of coming to Indonesia is to study Indonesian language and cultures at DSU. They mostly came from the countries which English was neither their first nor second languages. The unsystematic appointment of overseas teachers will likely to cause the undeveloped students' communication competence. The example is from teacher's point of view:

Yeah, to me it's a big issue because they are the one who are supposed to give a good education the good speaking environment for the students but they cannot provide that with the accurate English how our students can produce the right ones.

As one of the biggest university with greater international collaborations, to find out the right people for Speaking courses should not be an issue. With such prestigious status and money, DSU should able to select high qualified staff who meet the Department requirements and possess better teaching qualification.

Okay so maybe the university needs to hire better persons so not only relies on those who are just meant to be here and hire them with good money we can actually offer those money to better persons because I think the native speakers would be happy to work here I don't know what is actually the problem but yeah we are En-glish Department and we are supposed to have one at least one representative of native speakers because when I was a student I had I had one and he was he was good and I don't know why he's not here anymore but yeah we could hire right persons I don't know what hap-pens now.

\section{Streaming classes based on proficiency}

The speaking classes consisted of mixed ability students. Almost all communication teachers experienced difficulties handling mixed ability class. It is easy for students to get frustrated since stronger students may feel held back, weaker students may feel pressured. The teacher may feel pressured as well. One of the teachers described what she did was to create a classroom atmosphere where everyone in her class was talking freely with less apprehension. At this stage, her focus was to stimulate conducive classroom atmosphere for students to speak and did not worry much with the expected outcomes stated on the syllabuses.

Another concern was also expressed by a speaking teacher who argued that the university entrance requirement level made the syllabus unworkable. The entrance tests are supposed to discriminate able from unable students. However, even though the students' English did not meet university requirement, they were still accepted to study especially at English Department. Consequently, it is difficult to improve students' communication at the expected level. See the quotation from a teacher:

We have students with high proficiency and students with low or even no proficiency at all. So, some students can reach the goals even can pass the goals but some students can't even make half of it. For the students starting from zero proficiency we still have to teach like very basic English while the students with high proficiency we can we can offer high learning challenges.

In addition, teachers hoped to teach a smaller number of students for speaking class or less than twenty. This will give teacher enough time to focus on individual student communication performances. According to the teachers to give equal distribution of attention in a big size of the class can be daunting experiences. Despite the expressed concerns, no workshop and training or special meeting were conducted to minimize concerns. No speaking workshop was organized by the Department for quite some time. This is because almost all administrative jobs occupied the academic staff schedules. Some administrative tasks that staff were involved regularly are the Department accreditation, faculty graduation committees, staff meetings, Final test committees.

\section{Discussion}

There are several factors affect the development of communicative competence. At English Department DSU the factors include the unsystematic assessment of students' needs of communication, the shift of teaching paradigm, establishment of a variety of English exposure programs and facilities. Each discusses in more detail below.

\section{The unsystematic assessment of students' needs of communication}

There are several stark contrasts between teaching English at secondary and tertiary level in Indonesia. As it has been discussed earlier that curriculums and syllabuses at secondary schools are developed by using top-down approach. This approach will unlikely to give wider opportunity for both students' and teachers' communication development. However, at tertiary level educators are allowed to develop curriculum and syllabuses based on students' needs. Therefore, teaching and learning process at university should have been directed and designed to satisfy the needs of learners (Iwai, Kondo, Lim, Ray, Shimizu, \& Brown, 1999). If the lecturers have not understood learners' needs, they would not be sure how to help the learners to obtain optimal results. In Indonesia, very few reports identify oral English communication needs of Indonesian students at their tertiary level including at DSU classrooms. Needs Analysis (NA) studies have been noticeably carried out in many countries in Asia regions such as Pakistan, Malaysia, Thailand, Taiwan and Hong Kong. It showed that educators in many contexts are now moving forward to take into account that learners are the central part in their education systems. Their voices matter a lot. At the 
moment, at ED DSU, teachers admit not to have sufficient knowledge how to conduct the NA and trainings have never been offered to them.

\section{The shift of teaching paradigm}

Secondly, Since English Department students at DSU are projected to be both at lower and upper secondary school teachers, ED have encouraged students to take a brave step toward a new paradigm that is learning language in order to use it. This can be started from the lower secondary level. At the moment, majority teachers are still maintaining the grammatical teaching focus. English teaching which mostly focuses on grammar will, in the long run, affect their English competence at tertiary level. And with little or no significant communication development, university graduates will surely repeat the same teaching approach when they go into teaching careers.

For Example, Eslami-Rasekh and Valizadeh (2004) found that in Iran grammar translation predominates and there is little opportunity to use English for communicative purposes. Further, the the desire for change amongst teachers in this country is minimal. This is not surprising as the products of form-focused teaching, graduates are likely to repeat similar approaches later in their own teaching practices teaching the way they were taught. This has also been found in other contexts in Asian regions. Therefore, teaching institution like ED DSU ought not only to consider equipping students with English communication development but also to take brave steps and strong determination to adopt the right approach for students' communication development.

In order to achieve that, the issue need to be addressed was teachers' approach in communication class. Students have their own expectations of communication class (Holliday, 1994). The strategy of how the communication courses are carried out often teacher-centred. These learning experiences are in stark contrast to those commonly found in communicative classrooms which according Canale and Swain (1980) that communicative classroom teachings view that language learning and teaching should be about the use of the target language not understanding the rules of the target language. Specifically in Indonesia, communication classrooms are in between teacher-centred and learner-centred. Teachers are still needed as decision makers in the English materials selection whether they are as complementary, omission or negotiation. The teachers' roles are critical since they may understand the classroom situations better than the students. At the same time learners are given a freedom to decide the types and the level of communication that they are confident participating.

\section{The establishment of a variety of English exposure programs and facilities}

The two-credit speaking course or equal to 100 minutes is considered far from adequate to accommodate 20 to 25 students to speak. The limited time allocation for speaking courses makes the learning activities, such as pair or group discussions and getting feedback from classmates or lec- turers a big impossible. As a result, some students did not have the same chance to speak. Steiwi and Hamuda (2016) in their research, about $72 \%$ of students said that the time allocated for teaching the speaking at English Department is inadequate to help them practice to speak. Students are aware that in order to achieve better communication competence, they need to make some attempts outside classroom. Creating wider English exposure modes and enforce students to join is an alternative solution. Students' determination to expose themselves for instance by attending English forum, small group conversation, and self-practice are likely to increase their English oral ability. However, many students did not seem to take advantage the English exposures established by the ED at DSU. A few proficient students were willing to make the most of it, while others used avoidance strategy (Poedjiastutie, Warnanda, Saputro, Hima (2017).

\section{CONCLUSIONS}

A lot of aspects need to be taken into account for tertiary level students' communication development. The secondary schooling English instruction play crucial roles to prepare students' readiness at tertiary level. Having said that, as students embark on their higher education, they have sufficient learning experience to develop their expectations that educators. In general, one of several big issues in education that government should address is a clear connection between secondary schooling and university curriculums. And this can be achieved if top-down approach of curriculum development was negotiated.

Another crucial step is to train the educator in order to possess adequate knowledge and skills of NA. The NA can be conducted not only for students as the education consumers but also to other stakeholders, in addition to the government roles, at university level, a group of people involved in the development of English communication level should work had in hand to synchronize different expectations to work toward reducing the problematical issues. Especially at English Department DSU, the factors causing the undeveloped of students' communication level fall into three. The first is students' factors. Students expect the communication goals is to prepare them to secure in jobs other that teaching. This is a big contradictive with the Faculty of Education and Teacher Training's objectives and goals which prepare its students for the teaching careers. Students also explain their preference of communication teachers and expect them to have strong teaching commitment. Secondly, several factors are suspected to contribute to communication development such as the variety expectations of communication goals, teachers' attitude toward the syllabuses and their teaching beliefs that may affect the speaking delivery.

Last but not least is the ED and university policy makers are supposed to put serious attention to factors inhibiting the communication development like the big size of communication classes, heterogenous level of students' speaking ability, and the lack of teachers' determination. 


\section{REFERENCES}

Azra, A. (2002). Paradigma Baru Pendidikan Nasional: Rekonstruksi dan Demokratisasi (1 ${ }^{\text {st }}$ edition). Jakarta: Penerbit Buku Kompas. Agustin, D. T., Warsono, Mujianto, J. (2015). The Use of Bahasa Indonesia (L1) in the Intensive English (L2) Classroom. English Education Journal (EEJ), 5(1), 1 -9.

Bjork, C. (2005). Indonesian Education: Teachers, Schools, and Central Bureaucracy. New York and London: Routledge.

Bryman, A. (2012). Social research methods (4th Ed.) Oxford University Press, New York.

Canale, M., and Swain, M. (1980). Theoretical bases of communicative approaches to second language teaching and testing. Applied Linguistics, 1, pp. 1-47.

Coleman, H. (2010). The English language in development. Retrieved from www.teachingenglish.org.uk/transform/book

Crystal, D. (2003). English as a global language (2 ${ }^{\text {nd }}$ ed.). Cambridge: Cambridge University Press.

Erlandson, D.A., Harris, E.L., Skipper, B.L., \& Allen, S.D. (1993). Doing naturalistic inquiry: A guide to methods. Newbury Park, CA: Sage Publications.

Eslami-Rasekh, Z. \& Valizadeh, K. (2004). Classroom activities viewed from different perspectives: Learners' voice vs. teachers' voice. TESL EJ, 8(3), 1-13.

Febriyanti, E. R. (2011). Teaching speaking of English as a foreign language: problems and solutions. Jurnal Bahasa, Sastra, Dan Pembelajarannya., 1(2), 133-146.

Fraenkel, J. R., Wallen, N.E., \& Hyun, H.H. (2012). How to design and evaluate research in education ( $8^{\text {th }}$ ed.). New York: Mc Graw-Hill.

Guba, E.G., \& Lincoln, Y.S. (1989), Fourth generation evaluation. Newbury Park, California: Sage Publications.

Hamad, M. M. (2013). Factors negatively affecting speaking skills at Saudi colleges for girls in the south. English Language Teaching, 6(12), 87-97.

He, S. \& Chen, A.J.Y, (2010). How to Improve Spoken English. [Online] Available at: https://sites.google.com/ site/languagejournal/Home/how-to-improve-spokenenglish

Holliday, A. (1994). The house of TESEP and the communicative approach: The special needs of state English language education. ELT Journal, 48(1), 3-11.

Hosni, S.A. (2014) Speaking Difficulties Encountered by Young EFL Learners. International Journal on Studies in English Language and Literature (IJSELL), 2(6), PP. 22-30.

Huda, N. (2000). Kedudukan dan fungsi bahasa asing (The position and function of foreign languages). In H. Alwi, \& Sugono, D. (Ed.), Politik bahasa: risalah seminar politik bahasa (Language politics: procedings of the seminar on language politics). (pp. 59-78). Jakarta: $\mathrm{Pu}-$ sat Bahasa dan Departemen Pendidikan Nasional.

Iwai, T., Kondo, K., Lim, S. J. D., Ray, E. G., Shimizu, H., \& Brown, J. D. (1999). Japanese language needs analysis. Available at: http://www.nflrc.hawaii.edu/Networks/ NW13/NW13.pdf
Jenkins, J. (2003). World Englishes: A resource book for students. London and New York: Routledge English Language Introductions

Kayi, H. (2006). Teaching Speaking: Activities to Promote Speaking in a Second Language. The Internet TESL Journal, 12.11. EBSCOhost.

Lincoln, Y. \& Guba, E. (1985). Naturalistic Inquiry. Beverly Hills, CA: Sage.

McCombs, B. L. \& Whistler, J. S. (1997). The Learner-Centered Classroom and School. Strategies for Increasing Student Motivation and Achievement. San Francisco: Jossey Bass Publishers.

Miles, M. B., \& Huberman, A. M. (1994). Qualitative data analysis: An expanded source- book, (2nd ed.). Newbury Park, CA: Sage.

Munjayanah, A. (2004). The Implementation of Communicative Language. Jakarta: Bumi Aksara.

Poedjiastutie, D. and Oliver, R. (2017). Exploring Students' Learning Needs: Expectation and Challenges. ELT Journal 10(10), 124-133. DOI: https://doi.org/10.5539/ elt.v10n10p124

Poedjiastutie, D., Warnanda, K.N., Saputro, T.H., Hima, A.N. (2017). An Interpretive Study of the Communication Needs of English Department Students at University of Muhammadiyah Malang. JiNoP (Journal Innovasi Pembelajaran), 3(2), DOI: https://doi.org/10.22219/ jinop.v3i2

Rabab'ah, G. (2015). Communication problems facing Arab learners of English. Journal of Language and Learning, 3(1), ISSN 1740-4983.

Senel, M. (2012). Oral communication anxiety and problems of Turkish EFL learners at Samsun 19 Mayis University, ELT Department. Frontiers of Language and Teaching, 3, 49-58.

Shteiwi, A.A. and Hamuda, M.A. (2016). Oral communication Problems Encountering English Major Students: Causes \& Remedies. International Journal of Social Science and Humanities Research, 4(2), pp: (19-26). Available at: www.researchpublish.com

Tracer Study Team, ED. (2016). Borang Akreditasi: Tracer Study: English Department Universitas Muhammadiyah Malang.

English (L2) Classroom. Prodi Pendidikan Bahasa Inggris, Program Pascasarjana, Universitas Negeri Semarang, Indonesia.

Zacharias, N. T. (2003). A survey of tertiary teachers beliefs about English language teaching in Indonesia with regard to the role of English as a global language. Unpublished MA Thesis, Thailand University, August, 126.

Zuhdi, M. (2015). Pedagogical Practices in Indonesia. Transforming Teaching and Learning in Asia and the Pacific Case Studies from Seven Countries. UNESCO. Bangkok. 